\title{
Determination of Radon Content in Water Respecting to Directive of Council 2013/51/EURATOM
}

\author{
Adrian Jakowiuk1 ${ }^{1}$ Zuzanna Jarosz ${ }^{2}$, Sylwia Ptaszek ${ }^{1}$, tukasz Modzelewski' \\ Ewa Kowalska1, Katarzyna Wołoszczuk ${ }^{2}$ \\ ${ }^{1}$ Institute of Nuclear Chemistry and Technology, Warsaw, Poland \\ ${ }^{2}$ Central Laboratory for Radiological Protection, Warsaw, Poland \\ Email: a.jakowiuk@ichtj.waw.pl, z.jarosz@clor.waw.pl
}

Received 24 March 2015; accepted 18 July 2015; published 21 July 2015

Copyright (C) 2015 by authors and Scientific Research Publishing Inc.

This work is licensed under the Creative Commons Attribution International License (CC BY).

http://creativecommons.org/licenses/by/4.0/

(c) (i) Open Access

\section{Abstract}

In accordance with the recommendations of the most recent Directive of Council EURATOM No. 2013/51, which concerns requirements for the protection of the health of the general public with regard to radioactive substances in water intended for human consumption, we are obligated to monitor the level of approximate dose of radioactive substances. The directive indicates two basic isotopes: tritium and radon, which ought to be monitored continuously. Essential are also parametric values as well as frequency, methods of monitoring of radioactive substances and equipment requirements. Directive states that measurements of content of tritium and radon ought to be taken as well as calculations of approximate dose natural and artificial radionuclides content should be done, apart from tritium, potassium-40, radon and short-living products of radon disintegration. In case if one of radioactive concentrations is over $20 \%$ of computational value or concentration of tritium is over parametric value analysis of additional radionuclides is required. A detailed list of radionuclides is presented in appendix No. 3 in the Directive. Laboratory of Nuclear Control Systems and Methods in the Institute of Nuclear Chemistry and Technology (INCT) worked out a Miniature Liquid Scintillation Counter (LCS) [1] [2], within a project titled "New generation of intelligent radiometric devices with cordless transmission of information" (UDA-P0IG.01.03.0114-065/08) co-financed by European Union from the European Regional Development Fund (ERDF). This Miniature Liquid Scintillation Counter may be used as a basic equipment resulting in the above mentioned directive. This article presents results of conducted research based on LCS and comparison of this results with the measurements carried out by Accredited Laboratory for Calibration of Dosimetric and Radon Instruments in Central Laboratory for Radiological Protection in Warsaw (CLOR). 


\section{Keywords}

\section{Liquid Scintillation Counter, Radon in Water}

\section{Introduction}

\subsection{Measurement Procedures Prepared in LTJ-INCT}

Laboratory of Nuclear Control Systems and Methods (LTJ) prepared two measurement procedures, which are used to determine content of radon in water dedicated to measurements by the use of Liquid Scintillation Counter (LCS) [3].

The Miniature Liquid Scintillation Counter (Figure 1) constructed in the Laboratory of Nuclear Control Systems and Methods in the Institute of Nuclear Chemistry and Technology (INCT) for using in laboratory measurement conditions for needs of nuclear medicine (to control pharmaceutics), in hydrology (measurement of radon and tritium concentration in water) or in environmental protection. Two versions of Liquid Scintillation Counter were prepared:

- Counter for medical measurements (LCS-V1) - the measurement path consists of one photomultiplier, pulse amplifier, single channel analyzer and counter, which are controlled by dedicated computer program.

- Counter for environmental measurements (LCS-V2) — the measurement path consists of coincidences system of measurement signals from two photomultipliers (for reduction of photomultipliers noise), pulse amplifier, amplitude pulse analyzer and counter, working under control of dedicated computer program. The counter V2 has increased sensitivity and lowered own background in comparison with the counter LCS-V1.

Photomultipliers used in Liquid Scintillation Counter have low level of noise. Windows of $35 \mathrm{~mm}$ diameters collect light pulses of scintillation on photocathode from samples located on standard $20 \mathrm{ml}$ phial. In order to obtain measurement conditions stable, an automatic gain control system is used. A lightproof construction protects photomultiplier from daylight irradiation during inserting the samples into measurement system.

Liquid Scintillation Counter was optimized to measure concentration of alpha radionuclides (radon and its derivatives) and beta particles of energy over $100 \mathrm{keV}$. This counter possesses the best detection efficiency for radon over $90 \%$ and for carbon C-14 approximately 80\%. Its detection efficiency for tritium (H-3) is approximately $4 \%$. Tritium concentration in water measurements is possible using LCS-V2.

Measurement procedure 1 (500/20) — Pour $500 \mathrm{ml}$ of water sample in to cylinder, then add $25 \mathrm{ml}$ of liquid scintillator (Mineral Oil Scintillator-PerkinElmer company). After closing it you must mix everything energetically for 5 - 10 minute. The mixed sample needs to be put aside for 2 minutes until fractions of water and scin-

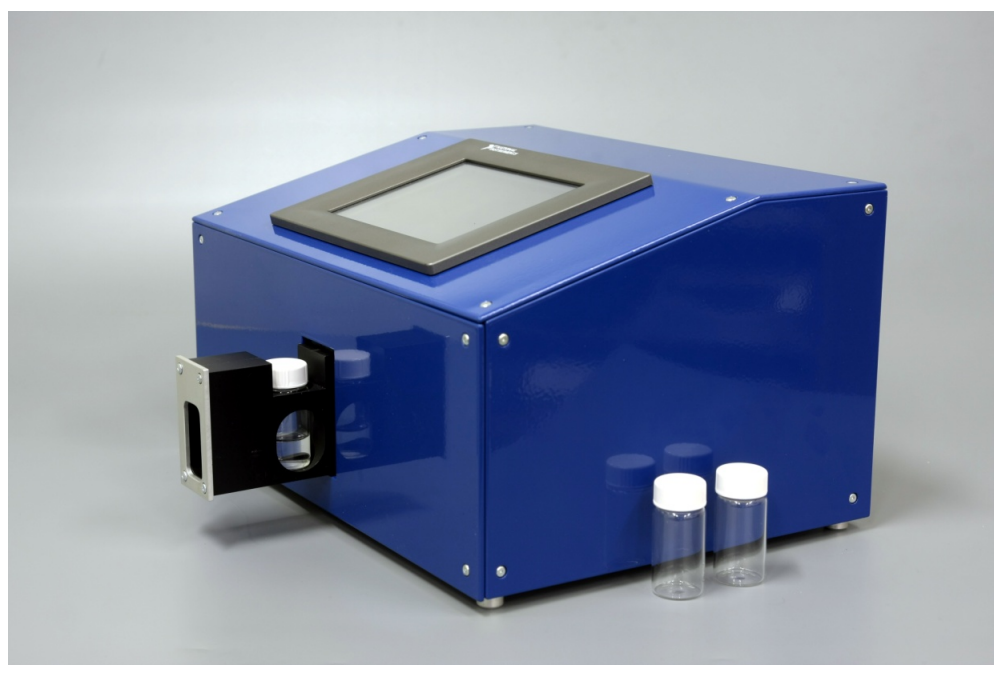

Figure 1. Liquid Scintillation Counter version LCS-V2.p. 
tillator are separated. From such a sample $20 \mathrm{ml}$ of scintillator must be taken out to scintillation phial. Measurement of radon concentration is possible after 3 hours. This time is needed to set balance between radon and products of its disintegration [4]. Conducting the measurement of the sample over 3 hours later its necessary to consider half-time of radon decay, which is 3.8 days.

Measurement procedure 2 (10/10) - it is a simplified measurement procedure. It is based on taking out $10 \mathrm{ml}$ of water sample to scintillation phial, then it is necessary to add $10 \mathrm{ml}$ of liquid scintillator to it (Mineral Oil Scintillator-PerkinElmer company). The received sample needs to be mixed energetically. Measurement of radon concentration is possible after 3 hours. Comparison of radon penetration rate from water into scintillator in case of mixing and not mixing sample vial is presented on Figure 2.

\subsection{Radon in Water Measurement Procedures Used in CLOR}

\subsubsection{Measurement of Radon in Water Samples Using AquaKIT and AlphaGUARD PQ2000 PRO}

In order to measure radon concentration in water system AquaKIT is used. This system is the additional equipment of radon monitor AlphaGUARD PQ2000 PRO.

Total measurement system (Figure 3) used in CLOR consists of following elements:

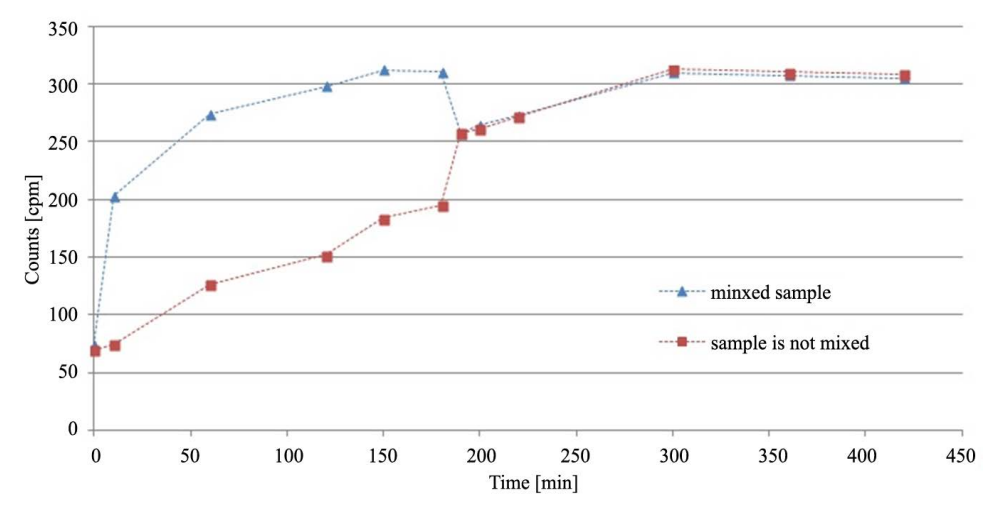

Figure 2. Comparison result of mixed and not mixed samples measurements. Background $=52 \mathrm{cpm}$. After $3 \mathrm{~h}$ since forming, both samples were mixed energetically.

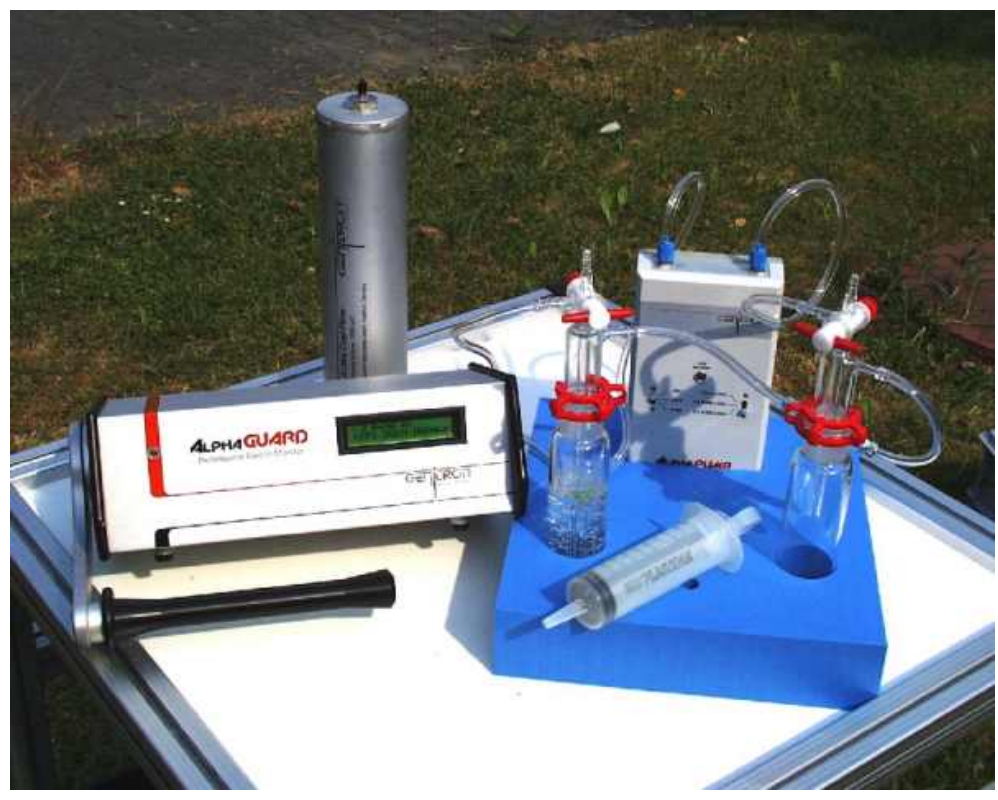

Figure 3. AquaKIT for radon in water measurement [5]. 
- radon monitor AlphaGUARD PQ2000 PRO,

- one glass degassing vessel with a volume of $190 \mathrm{ml}$,

- one glass security vessel with a volume of $190 \mathrm{ml}$,

- connecting tubes with an interior diameter of $4 \mathrm{~mm}$,

- AlphaPUMP.

All elements of measurement system ought to be connected according to the scheme (Figure 4). It is necessary to make sure that the direction of air flow in the system is appropriate (from degassing vessel through security vessel to the radon monitor). The use of security vessel protects the pump from possible water penetration from the sample.

Radon Monitor AlphaGuard has to be set on " 1 min. Flow" mode. The air flow on the AlphaPUMP pump ought to be set on $0.3 \mathrm{l} / \mathrm{min}$. until inserting the sample into the system, the pump is turned off.

It is necessary $100 \mathrm{ml}$ water sample pour in to the degassing vessel (of volume $190 \mathrm{ml}$ ) and close it tightly as fast as possible. Then put it into the right place of measurement system using a special degassing cap. The next step is degassing a sample. Firstly, turn on the pump for 10 minutes. The air circulates in this closed system and during this process radon gets out from water to air.

Another step it is a real measurement lasting approximately 20 minutes. The pump is switched off, but the system is connected without any change.

To calculate radon concentration in researched water sample $C_{\text {Water }}$ it is necessary to read over results recorded in memory of the monitor AlphaGUARD during 20 min real measurement.

Significant quantities necessary to estimate $C_{\text {Water }}$ parameter are: radon concentration in air indicated by device, average temperature during the measurement, volume of the sample and volume of the air in the closed measurement system (the volume of ionizating chamber inside the monitor, security and degassing vessels and the volume inside the connecting tubes).

The final result is calculated on the basis of Formula (1), taking into consideration the value of coefficient $k$ (Formula (2), diffusion coefficient), which depends on temperature.

$$
C_{\text {Water }}=\frac{C_{\text {Air }}\left(\frac{V_{\text {System }}-V_{\text {Sample }}}{V_{\text {Sample }}}+k\right)-C_{0}}{1000}
$$

$C_{\text {Water }}-\mathrm{Rn}$ concentration in water sample $[\mathrm{Bq} / \mathrm{l}]$

$C_{\text {Air }}-\mathrm{Rn}$ concentration in the measuring set-up (indicated by AlphaGUARD) [Bq/ $\left.\mathrm{m}^{3}\right]$;

$C_{0}$ - Rn concentration in the measuring set-up before sampling $\left[\mathrm{Bq} / \mathrm{m}^{3}\right]$;

$V_{\text {System }}$-interior volume of the measurement set-up [ml];

$V_{\text {Sample }}$-volume of the water sample [ml];

$k$-radon diffusion coefficient;

$$
k=0.106+0.405 \mathrm{e}^{(-0.052 \cdot \mathrm{T})}
$$

$T$-temperature of water $\left[{ }^{\circ} \mathrm{C}\right]$

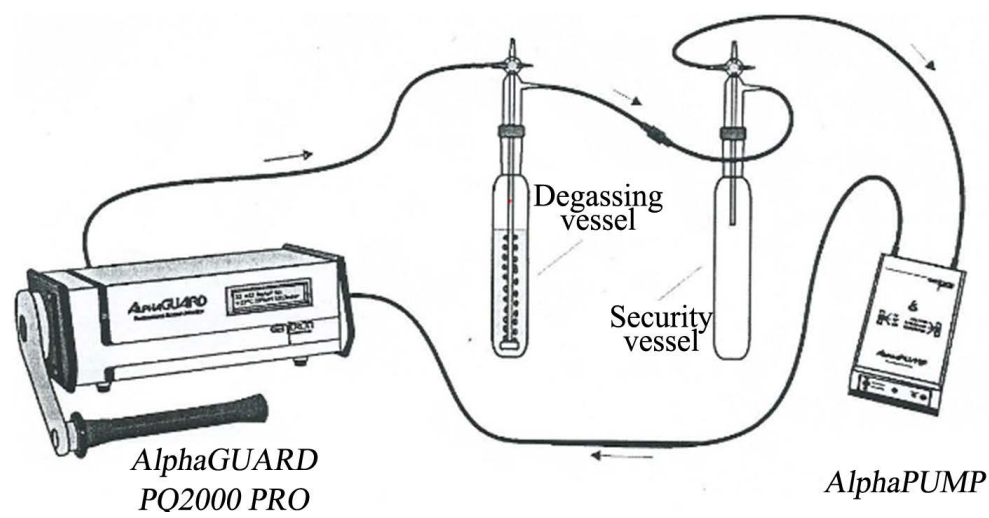

Figure 4. Connection scheme of measurement system AquaKIT [6]. 


\subsubsection{Determination of Radon in Water Concentration by the Use of Scintillation Counter TRI-CARB}

The measurement procedure is based on taking out a sample containing $10 \mathrm{ml}$ of water and putting it to each of five glass scintillation phials, then $10 \mathrm{ml}$ of liquid scintillator (OPTI-FLUOR-company PerkinElmer) is added. In addition, it is necessary to prepare one sample only with liquid scintillator in order to set the background and next to set MDC (minimal detection value) for specified measurement time.

Samples should be closed tightly and put aside for 3 hours, and then place them in counter case TRI-CARB 1900 belonging to Packard-Canberra company. Meanwhile, radon moves to scintillator and sets balance.

Measurement parameters can be set depending on the needs. In order to obtain better accuracy of results it is necessary to prolong time of single measurement and conducting at least three measurement cycles of each sample series, for example number of water samples- $3+1$ (zero sample), measurement time of single sample-15 minutes, number of cycles- 5 .

\section{Comparison Results of Measurements Carried out in INCT and CLOR}

There were carried out comparative measurements on different radon concentration samples. Samples were made by inserting containing radon air to water. [7] From such pre-prepared water taken out samples and next prepared according to the procedures:

- INCT-procedure No. 1 (500/20) and procedure No. 2 (10/10).

- CLOR-measurement by the use of monitor AlphaGUARD and Liquid Scintilation Analyser TRI-CARB). Measurement results are presented in Table 1 and illustrated in Figure 5.

After measurement on the basis of obtained results, calibration curves were draw up for procedure no 1 and 2 as well as for measurements by the use of analyzer TRI-CARB. The curves are presented in Figure 6 . The following coefficients of straight line slope were obtained:

- procedure no. 1: 0.0274 Bq////cpm;

- procedure no. 2: 0.4464 Bq///cpm;

- CLOR TRI-CARB: $0.4236 \mathrm{~Bq} / \mathrm{l} / \mathrm{cpm}$.

These values are true only for stable parameters arranged in measurement procedures.

In order to check detection efficiency of particular procedures used in INCT, there were carried out four measurements of different activity radon water. Radon water was obtained by inserting into the air system some specific radon value $\left(\mathrm{V}_{\mathrm{r}}\right)$ of stable but unknown activity Water in the system was subjected to the process of ae-

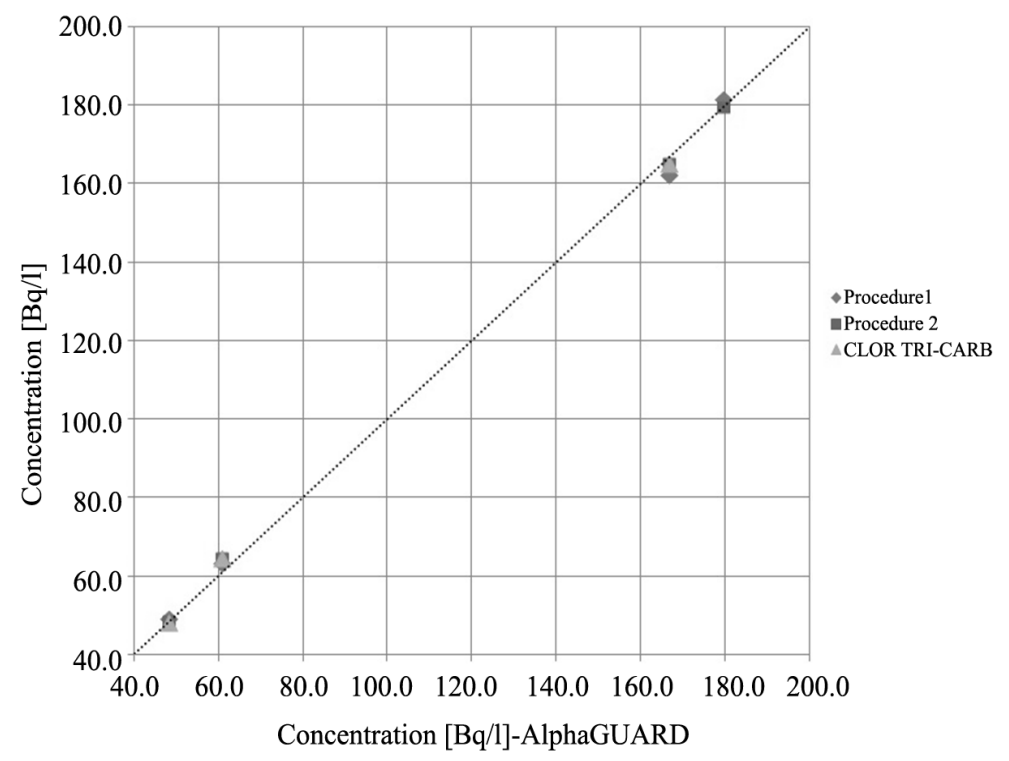

Figure 5. Results of radon concentration in water measurements according to INCT methods (Proc_1, Proc_2) and TRI-CARB method in comparison with obligatory procedure AlphaGUARD in CLOR. 
The calibration curves for the procedure 1

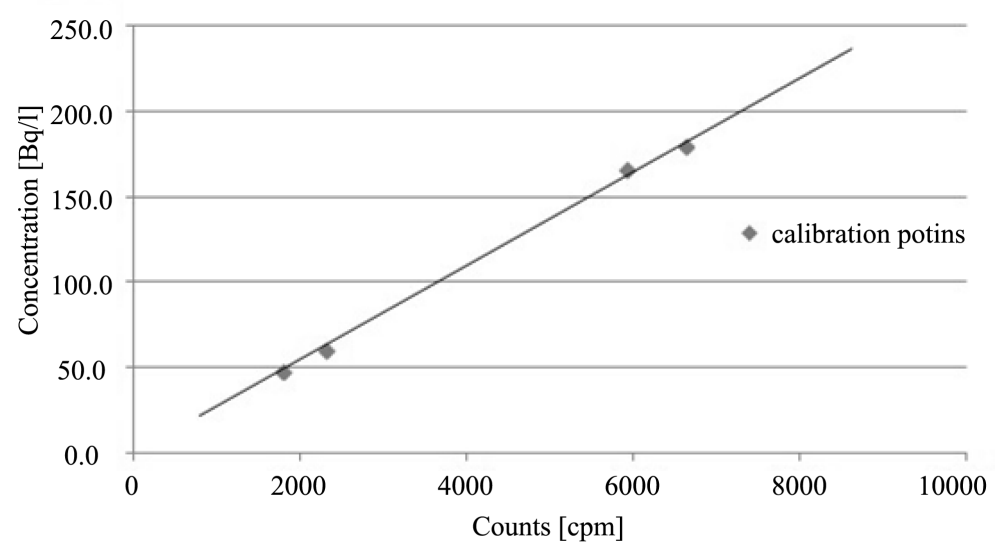

The calibration curves for the procedure 2

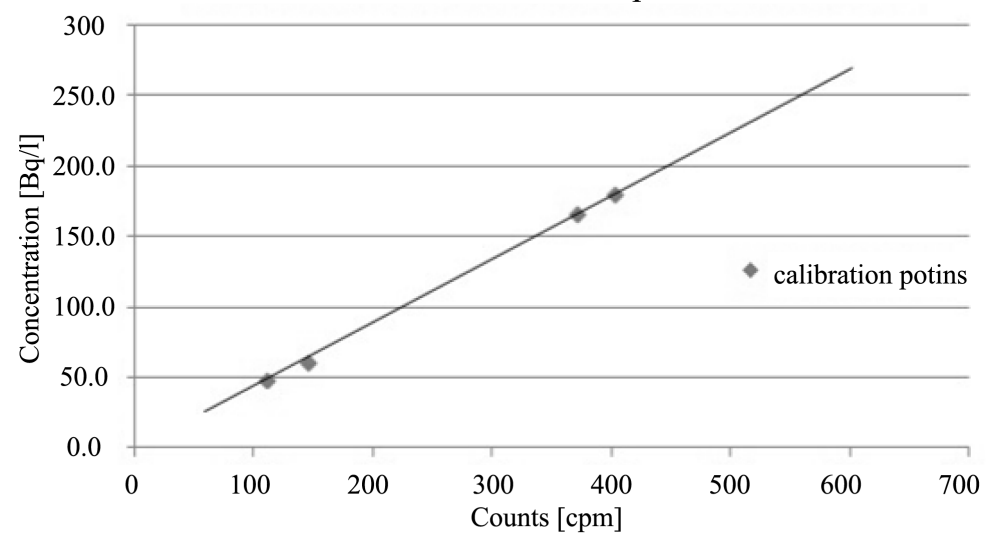

The calibration curves for the CLOR 2 (TRI-CARB)

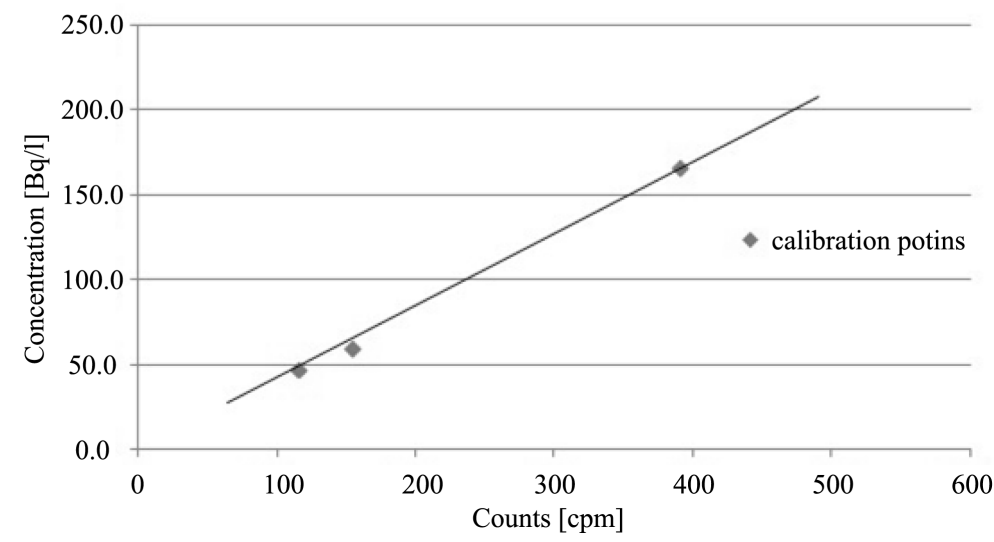

Figure 6. Calibration curves for procedure 1 and 2 used in INCT and measurements with the use of analyzer TRI-CARB (CLOR).

ration for 20 minutes. From such a radon water were taken out two samples. One of them was prepared according procedure $1(500 / 20)$, the second one procedure $2(10 / 10)$. Time of background and sample measurement was $10 \mathrm{~min}$, level of the background for the sample in procedure 1 was $78 \pm 4 \mathrm{cpm}$, in procedure 2 was $49 \pm 3$ cpm. The minimal value of detection (MDC) was 7.5 and $5.9 \mathrm{cpm}$, which gives 0.21 and $2.66 \mathrm{~Bq} / \mathrm{l}$. The ratio of water samples volume to measurement $\mathrm{V}_{\mathrm{w} 1} / \mathrm{V}_{\mathrm{w} 2}$ is 50 . The obtained measurement results are presented in Table 2. The average ratio of measured count levels for procedure $1\left(\mathrm{P}_{1}\right)$ to those obtained in procedure $2\left(\mathrm{P}_{2}\right)$ is 
Table 1. Comparison between INCT and CLOR methods of radon concentration in water measurements.

\begin{tabular}{|c|c|c|c|c|c|c|c|}
\hline \multirow{2}{*}{ 苂 } & \multicolumn{2}{|c|}{$\begin{array}{c}\text { CLOR 1 } \\
\text { (AlphaGUARD) } \\
\text { Reference method }\end{array}$} & & & $\begin{array}{c}\text { CLOR } 2 \\
\text { (TRI-CARB) }\end{array}$ & $\begin{array}{c}\begin{array}{c}\text { INCT } \\
\text { (Procedure 1) }\end{array} \\
\mathbf{5 0 0 / 2 0} \\
10\end{array}$ & $\begin{array}{c}\text { INCT (Procedure 2) } \\
10 / 10\end{array}$ \\
\hline & $\begin{array}{l}\mathrm{CP}[\mathrm{min}] \\
\mathrm{V}_{\mathrm{w}}[\mathrm{ml}] \\
\mathrm{V}_{\mathrm{p}}[\mathrm{ml}]\end{array}$ & $\begin{array}{c}20 \\
100 \\
1002\end{array}$ & $\begin{array}{l}\text { CP } \\
\text { TŁO } \\
\text { MDC } \\
\text { WSP }\end{array}$ & $\begin{array}{l}{[\mathrm{min}]} \\
{[\mathrm{cpm}]} \\
{[\mathrm{cpm}]}\end{array}$ & $\begin{array}{c}15 \\
16 \mathrm{~cm} \\
2.8 \\
0.4236\end{array}$ & $\begin{array}{c}10 \\
78 \\
7.5 \\
0.0274\end{array}$ & $\begin{array}{c}10 \\
49 \\
5.9 \\
0.4464\end{array}$ \\
\hline & $\begin{array}{c}\mathrm{C}_{\mathrm{Air}}\left[\mathrm{Bq} / \mathrm{m}^{3}\right] \\
\mathrm{T}\left[{ }^{\circ} \mathrm{C}\right]\end{array}$ & $\begin{array}{c}16,262 \pm 4.1 \% \\
23.7\end{array}$ & \multicolumn{2}{|c|}{$\mathrm{N}$ [cpm] } & $390 \pm 2.3 \%$ & $5926 \pm 1.3 \%$ & $370 \pm 5 \%$ \\
\hline 1 & $\begin{array}{c}\mathrm{k} \\
\mathrm{C}_{\text {Water }}[\mathrm{Bq} / \mathrm{l}]\end{array}$ & $\begin{array}{c}0.224 \\
166.7 \pm 6.8\end{array}$ & \multicolumn{2}{|c|}{$\mathrm{C}_{\text {Water }}[\mathrm{Bq} / \mathrm{l}]$} & $165.2 \pm 3.8$ & $162.4 \pm 2.1$ & $165.2 \pm 8.3$ \\
\hline \multirow{2}{*}{2} & $\begin{array}{c}\mathrm{C}_{\mathrm{Air}}\left[\mathrm{Bq} / \mathrm{m}^{3}\right] \\
\mathrm{T}\left[{ }^{\circ} \mathrm{C}\right]\end{array}$ & $\begin{array}{c}17,181 \pm 3.9 \% \\
25.0\end{array}$ & \multicolumn{2}{|c|}{$\mathrm{N}$ [cpm] } & $377 \pm 1.5 \%$ & $6626 \pm 1.1 \%$ & $402 \pm 5 \%$ \\
\hline & $\mathrm{C}_{\text {Water }}[\mathrm{Bq} / \mathrm{l}]$ & $\begin{array}{c}0.216 \\
\mathbf{1 7 9 . 5} \pm \mathbf{7 . 0}\end{array}$ & \multicolumn{2}{|c|}{$\mathrm{C}_{\text {Water }}[\mathrm{Bq} / \mathrm{l}]$} & rejected & $181.6 \pm 2.0$ & $179.5 \pm 9.0$ \\
\hline \multirow{2}{*}{3} & $\begin{array}{c}\mathrm{C}_{\text {Air }}\left[\mathrm{Bq} / \mathrm{m}^{3}\right] \\
\mathrm{T}\left[{ }^{\circ} \mathrm{C}\right]\end{array}$ & $\begin{array}{c}4719 \pm 5.6 \% \\
27.0\end{array}$ & \multicolumn{2}{|c|}{$\mathrm{N}$ [cpm] } & $114 \pm 2.8 \%$ & $1805 \pm 1.7 \%$ & $109 \pm 10 \%$ \\
\hline & $\begin{array}{c}\mathrm{k} \\
\mathrm{C}_{\text {Water }}[\mathrm{Bq} / \mathrm{l}]\end{array}$ & $\begin{array}{c}0.205 \\
\mathbf{4 8 . 3} \pm \mathbf{2 . 7}\end{array}$ & \multicolumn{2}{|c|}{$\mathrm{C}_{\text {Water }}[\mathrm{Bq} / \mathrm{l}]$} & $48.3 \pm 1.4$ & $49.5 \pm 0.8$ & $48.7 \pm 4.9$ \\
\hline \multirow{2}{*}{4} & $\begin{array}{c}\mathrm{C}_{\text {Air }}\left[\mathrm{Bq} / \mathrm{m}^{3}\right] \\
\mathrm{T}\left[{ }^{\circ} \mathrm{C}\right]\end{array}$ & $\begin{array}{c}5942 \pm 5.2 \% \\
21.1\end{array}$ & \multicolumn{2}{|c|}{$\mathrm{N}$ [cpm] } & $153 \pm 2.5 \%$ & $2315 \pm 2.1 \%$ & $145 \pm 3.5 \%$ \\
\hline & $\begin{array}{c}\mathrm{k} \\
\mathrm{C}_{\text {Water }}[\mathrm{Bq} / \mathrm{l}]\end{array}$ & $\begin{array}{c}0.241 \\
61.0 \pm 3.2\end{array}$ & \multicolumn{2}{|c|}{$\mathrm{C}_{\text {Water }}[\mathrm{Bq} / \mathrm{l}]$} & $64.8 \pm 1.6$ & $63.4 \pm 0.7$ & $64.7 \pm 2.3$ \\
\hline
\end{tabular}

Where: $\mathrm{V}_{\mathrm{w}}$-volume of water sample used to measure in the monitor AlphaGUARD, $\mathrm{V}_{\mathrm{p}}$-volume of air in measurement system of the monitor AlphaGUARD with AquaKIT, CP—-measurement time, TŁO—value of the background, MDC—minimal detection value, N—registered number of counts, $\mathrm{T}$-measurement temperature, $\mathrm{k}$-radon diffusion coefficient in water in temperature $\mathrm{T}$, WSP — calibrating coefficient, quotient of radon concentration value in water $[\mathrm{Bq} / \mathrm{l}]$ to number of counts $[\mathrm{cpm}]($ calculating counts $[\mathrm{cpm}]$ into concentration $[\mathrm{Bq} / \mathrm{l}])$.

Table 2. Results of measurements carried out on samples having different radon concentration in water. Comparison of two INCT methods.

\begin{tabular}{|c|c|c|c|c|c|c|}
\hline \multirow{2}{*}{$\mathbf{V}_{\mathbf{r}}$} & \multirow{2}{*}{$\begin{array}{l}\text { Preparation time } \\
\text { [min] }\end{array}$} & \multicolumn{2}{|c|}{ Procedure 1 (500/20) } & \multicolumn{2}{|c|}{ Procedure 2 (10/10) } & \multirow{2}{*}{$\mathrm{P}_{1} / \mathrm{P}_{2}$} \\
\hline & & P1 counts [cpm] & concentration $[\mathrm{Bq} / \mathrm{l}]$ & P2counts [cpm] & concentration [Bq/l] & \\
\hline \multirow{4}{*}{$60 \mathrm{ml}$} & 10 & $1550 \pm 38$ & & $92 \pm 11$ & & 16.9 \\
\hline & 60 & $1700 \pm 31$ & & $102 \pm 17$ & & 16.7 \\
\hline & 120 & $1795 \pm 34$ & & $104 \pm 7$ & & 17.3 \\
\hline & 180 & $1805 \pm 30$ & $49.5 \pm 0.8$ & $109 \pm 11$ & $48.7 \pm 4.9$ & 16.6 \\
\hline \multirow{4}{*}{$90 \mathrm{ml}$} & 10 & $1746 \pm 60$ & & $96 \pm 9$ & & 18.2 \\
\hline & 60 & $2195 \pm 54$ & & $134 \pm 9$ & & 16.4 \\
\hline & 120 & $2286 \pm 50$ & & $142 \pm 3$ & & 16.1 \\
\hline & 180 & $2315 \pm 49$ & $63.4 \pm 0.7$ & $145 \pm 5$ & $64.7 \pm 2.3$ & 16.0 \\
\hline \multirow{4}{*}{$120 \mathrm{ml}$} & 10 & $2083 \pm 63$ & & $114 \pm 10$ & & 18.3 \\
\hline & 60 & $2567 \pm 33$ & & $167 \pm 11$ & & 15.4 \\
\hline & 120 & $2780 \pm 34$ & & $183 \pm 8$ & & 15.2 \\
\hline & 180 & $2808 \pm 30$ & $76.9 \pm 0.8$ & $187 \pm 7$ & $83.5 \pm 3.1$ & 15.0 \\
\hline \multirow{4}{*}{$360 \mathrm{ml}$} & 10 & $3981 \pm 124$ & & $270 \pm 11$ & & 14.7 \\
\hline & 60 & $5329 \pm 81$ & & $366 \pm 19$ & & 14.6 \\
\hline & 120 & $6566 \pm 81$ & & $382 \pm 14$ & & 17.2 \\
\hline & 180 & $6626 \pm 73$ & $181.6 \pm 2.0$ & $402 \pm 22$ & $179.5 \pm 9.0$ & 16.5 \\
\hline \multirow{4}{*}{$480 \mathrm{ml}$} & 10 & $5624 \pm 142$ & & $286 \pm 16$ & & 19.7 \\
\hline & 60 & $7166 \pm 94$ & & $418 \pm 22$ & & 17.1 \\
\hline & 120 & $7882 \pm 56$ & & $474 \pm 13$ & & 16.6 \\
\hline & 180 & $8026 \pm 91$ & $219.9 \pm 2.4$ & $494 \pm 18$ & $220.5 \pm 8.3$ & 16.2 \\
\hline
\end{tabular}


16.05. The ratio of calibration coefficient for procedure 2 to procedure No. 1 is 12.91 .

\section{Conclusions}

Directive of Council EURATOM No. 2013/51 concerning health protection of population with reference to radioactive substances, which are present in water drunk by people, defines acceptable amount of radon on the level of $\mathrm{Bq} / \mathrm{l}$. Directive specifies detection boundary on the level of $10 \mathrm{~Bq} / \mathrm{l}$. Both procedures used in INCT and CLOR which are presented in the article fulfill the above-mentioned requirements. The smallest detection boundary $(0.21 \mathrm{~Bq} / \mathrm{l}$ with the time of measurement $-10 \mathrm{~min})$ was obtained in procedure 1 used in INCT. This procedure should be used because of its higher sensitivity in order to measure water with lower radon concentration. To general assessment of radon concentration in water, it is advisable to use procedure 2 which is more simple to use and gives satisfying results.

During the measurements noted that mixing prepared water samples with the scintilator by energetic shaking shortens the time after which it is possible to measure the samples. It accelerates the process of passing radon from water to the scintilator and helps to set balance. The mixed samples can obtain maximum counts number just after three hours, while the samples which are not mixed, after five hours.

The research presents accordance of results obtained by Laboratory of Nuclear Control Systems and Methods in the Institute of Nuclear Chemistry and Technology with the results received by the Laboratory for Calibration of Dosimetric and Radon Instruments in Central Laboratory for Radiological Protection in Warsaw.

The INCT Miniature Liquid Scintillation Counter is very suitable device for routine measurements of radon content in water according to EUROATOM Directive.

\section{Acknowledgements}

The work was realized in the frame of an international project co-funded-Ministry of Science and Higher Education Republic of Poland- "Development of dosimetry methods and safety of radiation and nuclear facilities", within the framework of the project "Global Threat Reduction Initiative” based on contract No. 212971— Task Order 38.

\section{References}

[1] Bartak, J., Machaj, B. and Pieńkos, J. (2002) Apparatus for Measuring Radon Concentration in Air. Nuclear Technology in Industry, Medicine, Agriculture and Environment. Institute of Nuclear Chemistry and Technology, Warsaw, 303-312.

[2] Jakowiuk, A., Pieńkos, P.J., Kowalska, E., Filipiak, P. and Świstowski, E. (2012) Wireless System for Radiometric Measurements. Nukleonika, 57, 637-641.

[3] Passo, C.J. and Cook, G.T. (1994) Handbook of Environmental Liquid Scintillation Spectrometry: A Compilation of Theory and Methods. Packard Instrument Company.

[4] Machaj, B. and Urbański, P. (1999) Continuous Measurement of Radon Concentration in the Air with the Lucas Cell by Periodic Sampling. Nukleonika, 44, 579-594.

[5] http://saphymo.de/products/slides/alphaslide14.html

[6] AquaKIT-manual 12/2008, Saphymo GmbH, Germany.

[7] Machaj, B. and Pieńkos, J. (2003) Pomiar stężenia radonu w wodzie za pomocą komory Lucasa. Raporty IChTJ seria B nr 1/2003, Instytut Chemii i Techniki Jądrowej. 